\title{
Early childhood education in Vietnam, history, and development
}

Thao Thi $V u^{1,2^{*}}$ (1)

\author{
${ }^{*}$ Correspondence: \\ vuthao2801@gmail.com \\ ${ }^{1}$ Murdoch University, \\ Western Australia, Australia \\ Full list of author information \\ is available at the end of the \\ article
}

\begin{abstract}
Vietnam has an age-old history of education, and Vietnamese people have high respect for learning. However, early childhood education (ECE) in Vietnam has been the main concern only since 1945. This paper describes the process of establishment and development of ECE in Vietnam. Before and during the French colonial period in Vietnam, early childhood education was not considered a social task, and therefore, there was no formal educational system and curriculum for preschool children at this time. After 1945, with the great transformation of history, Vietnamese education has changed dramatically so that from 1945 to 1975 it was a period of political, social and educational separation. The historical events affect the education system and early childhood education in Vietnam. Consequently, the history of ECE in Vietnam is separated into two main phases, before and after 1975. Through the ups and downs of history, Vietnam has successfully built the ECE system. Over seven decades of development, ECE in Vietnam has made remarkable changes. The change comes not only from the expansion of the number of educational institutions, but also from the curriculum and pedagogy that are considered as the most important changes. Gradually escaping the influence of teacher-centered pedagogy, Vietnamese ECE is aiming to build a childcentered education, thereby helping learners to reach their full potential.
\end{abstract}

Keywords: Early childhood education, Vietnam, ECE history Vietnam, ECE development Vietnam

\section{Introduction}

Vietnam has an age-old history of education, and Vietnamese people have high respect for learning. However, early childhood education (ECE) in Vietnam has been a main concern only since 1945 . This practice reflects Vietnamese traditional convention of a relationship between mothers and children. Mothers and grandmothers are expected to look after a baby until he/she can go to primary or secondary schools (Pham et al., 2006).

This paper describes the process of establishment and development of ECE in Vietnam. Before and during the French colonial period (from 1884 to 1945), ECE was not considered a social task, so there was no formal educational system and curriculum for preschool children at this time. Only a few preschool classes were operated in French schools, and a week-long kindergarten was run in Hanoi (The Vietnam Institute of Educational Sciences, 1991 as cited by Vasavakul 2000). There were several charitable centers

(c) The Author(s) 2021. This article is licensed under a Creative Commons Attribution 4.0 International License, which permits use, sharing, adaptation, distribution and reproduction in any medium or format, as long as you give appropriate credit to the original author(s) and the source, provide a link to the Creative Commons licence, and indicate if changes were made. The images or other third party material in this article are included in the article's Creative Commons licence, unless indicated otherwise in a credit line to the material. If material is not included in the article's Creative Commons licence and your intended use is not permitted by statutory regulation or exceeds the permitted use, you will need to obtain permission directly from the copyright holder. To view a copy of this licence, visit http://creativeco mmons.org/licenses/by/4.0/. 
that supported orphaned children in big cities such as Soeur Antoine orphanage in Hang Bot Street and a welfare center named Te Sinh in Sinh Tu street (or Nguyen Khuyen Street) in Hanoi. Although in Hanoi and Hue there were some classrooms for preschool children (under 6 years old) in Albert Sarraut school and the private girls school Jeanne d'Arc, these classrooms were only opened for teaching French children and Vietnamese children born in aristocratic families. Subsequently, almost all children were nurtured and educated by their families (Pham et al., 2006).

From 1945 to 1975, Vietnam was immersed in two bloody wars against the French colonists (1945-1954) and American occupation (1954-1975). This period was marked by two crucial moments, which split of the country since 1954 and unification of the country in 1975. The wartime led to a period of political, social, and educational separation between the North and the South in Vietnam. Consequently, the early childhood education in Vietnam was influenced by this separation. As a result, the history of ECE in Vietnam is separated into two main phases, 1945-1975 and 1975-present.

\section{Early childhood education in Vietnam from 1945 to 1975}

\section{ECE in Democratic Republic of Vietnam (DRV)—North Vietnam}

After the victory of the August Revolution in 1945, the government of the Democratic Republic of Vietnam (DRV) signed Decree 146 on August 10th, 1946 to set up fundamentals of a new educational system. The period from 1945 to 1954 was the time for an initial formation of ECE in Vietnam. At this time, ECE was referred as Infantile Education Level (Bậc học Ấu trĩ). Article 3 the Decree 146 asserted created the Infantile Education Level (Bậc học Ấu trĩ), designed for the children under seven that would be managed and implemented by the Ministry of Education (MOE) (Democratic Republic of Vietnam, 1946; Vasavakul, 2000). Two years later, although Infantile education was quickly expanded, its quality was poor because of its spontaneous development. In order to solve the dearth of curriculum, educational philosophy, teachers' competencies, and learning materials, the first national kindergarten conference was held in November 1949 and proposed a new perspective on ECE (Pham et al., 2006). Two main purposes of Infantile Education approved in this conference were (1) to train children to become good citizens of the newly democratic country, and (2) to emancipate women from childcare duties in order to have spare time for studying and working (Pham et al., 2006). Although the conference focused on discussing the reasons for setting up Infantile Education, it did not mention how to develop the curriculum and how to identify specific requirements for different disciplines such as child health and children's language development for the Infantile Education Level. However, the conference affirmed the main point that in the Infantile Education Level, children learn through playing and classrooms should be flexible and suitable for the economic situation of each geographic area.

In 1950, the government of the Democratic Republic of Vietnam implemented the first educational innovation, and Nursery Education (Mẫu giáo) replaced Infantile Education (Bậc học Ấu trĩ). This initiative was inspired by from a book entitled "Mẫu giáo" written by Deputy Minister of Education Nguyen Khanh Toan in 1949 (Pham et al., 2006). In Chinese-Vietnamese, "Mẫu giáo" means teaching by mother and Nguyen Khanh Toan (1949) used this term to suggest that kindergarten teachers should be female as "woman 
had innate motherly virtues or were able to acquire such virtues" (Vasavakul, 2000, p. 217). His reasoning for "Mẫu giáo" was that "mothers were traditionally considered home educators and children of kindergarten age remained under their mother's influence" (Nguyen Khanh Toan, 1991, as cited by Vasavakul, 2000, p. 217). After that, the Nursery Division under the MOE was established in July 1950 (Decree No. 404), which mandates three main roles including (1) setting up curriculum and plans used for teaching children from 3 to 6 or 7 years old, (2) promoting further education and training for teachers, (3) spreading knowledge in raising a child for community, and (4) supporting local governments to open new kindergartens. Subsequently, qualifications of teachers were improved in 1950 and 1951 (Pham et al., 2006). According to Pham et al. (2006), the Ministry of Education decided to conduct a pilot at Ấm Thượng Kindergarten (Phu Tho) to identify pedagogical methods to be used in kindergartens and to develop training materials for in-service educational program based on three books, namely "Mẫu giáo"-"Kindergarten" (Nguyen Khanh Toan, 1949), "Phương pháp giáo dục trẻ em""Methods for educating children" (Hoang Xuan Nhi, 1949 as cited in Pham et al,. 2006) and "Dạy con- đức dục ở trường mẫu giáo"- "Teaching children-moral education in kindergarten" (Pham Loi, 1950 as cited in Pham et al., 2006). It is considered as the initial step to set up the views and theoretical issues of early childhood education in Vietnam in the early 1950s (Pham et al., 2006).

The book "Kindergarten" mentioned fundamental issues such as (1) the purpose of preschool education in Vietnam was to raise children to become new citizens of a new democratic country, (2) teaching methods must be flexible, combining both playing and learning, and (3) flexible classroom arrangements depended on actual conditions of each geographical areas, and teachers should utilize the natural materials to make toys for children. "Methods for educating children by Hoang Xuan Nhi (1949 as cited in Pham et al., 2006)" identifies developmental stages of a child and propose active education. $\mathrm{He}$ insisted that children acquire knowledge and develop their cognition by interacting with surroundings and nature. If the first two books focus on underlying theoretical issues, a book "Teaching Children-Moral Education in Kindergarten" by Pham Loi (1950, as cited in Pham et al., 2006) focuses on the specific issues on moral education that teachers can read and follow some easy instructions (Pham et al., 2006).

From January 1950, the Central Kindergarten Board (Ban mẫu giáo Trung ương) initiated a program for training kindergarten teachers. Due to the fierce war and bombs dropped throughout the country, the training program was sometimes delayed, or the classes were moved to a new location. By the end of 1951, the Kindergarten Board had trained 220 teachers. Kindergartens were extended in the form of "pilot" and used the "snowball" method to open new schools in different provinces. In the 2 years of 1950 and 1951, kindergartens did well to contribute to the liberation of women's labor and set up well-organized care and education for preschool children (Pham et al., 2006). The development of early childhood education based on the contribution from parents in this period and it showed embryonic signs for the socialization of education in Vietnam (that will be discussed further in the 1990s in this chapter).

Nursery education from 1945 to 1954 started to build the management system and developed curriculum in schools as well as teacher education program. Although the MOE took a lot of effort on teacher education and constructing kindergartens, ECE in 
Vietnam in this wartime had to face many difficulties. First, because the training time was too short and the teaching materials were poor, teachers gained limited knowledge about early childhood education. As a result, after a few months of teaching, attendance was poor (Pham et al., 2006). In addition, once the war had been more fierce, the first grade in primary education was on the first list of priorities instead of nursery education. At that time, the top priority was given to education for the children between six and twelve because they did not experience the first grade, and they were too old to be enrolled at kindergarten. Thus, a class called "Vơ lòng" (beginners' class) was set up in 1952 by turning existing kindergarten classes into "Vỡ lòng" classes, and, after 1954, this kind of class focused on supporting children between 8 and 11 years old. This program included different aspects such as reading, writing, and arithmetic on Saturdays and the total time for this program was 9 months (Vasavakul, 2000). Since then, the Kindergarten Board (Ban mẫu giáo) was moved directly under the Department of General Education (Nha giáo dục phổ thông), and it oversaw both kindergarten classes and beginners' classes.

In 1951, because of an urgent situation for the revolution, the Vietnam Women's Union asserted that it was necessary to create favorable conditions for the members of the Central Association to fulfill their revolutionary duties by looking after their children, the first boarding-kindergarten was constructed in Vietnam such as Khe Khao camp (Bắc Cạn) and a Military Camp to raising young children whose parents were fighting on the front lines. The experience in setting up this boarding school helped Vietnamese educators to successfully construct kindergarten schools later, during the anti-American resistance. Although it was difficult to promote nursery education in wartime, the total number of children going to kindergarten in northern and central Vietnam was 1193 (in 46 classrooms) and 1200 (in 30 classrooms), respectively, in 1951 (Pham et al., 2006). These numbers provide clear evidence of the expansion of early childhood education in Vietnam from 1945 to the 1950s.

After winning the historical battle Dien Bien Phu in 1954, from 1954 to 1964 was the peaceful time in the North of Vietnam, and it was a good opportunity for the Government of DRV to create a new society. The evolution of education had brought about a deep change in ideology and consciousness. After 1958, nursery education (for children under 6 years old) was a priority again due to women's increasing participation in the labourforce in the North of Vietnam. First, women went to work in urban areas in Vietnam to earn work points after the first Five-year Plan, which called for socialist industrialization, was approved in 1960. Second, from 1965 to 1968, the war in southern Vietnam became more fierce, so men went to the front lines and women had to work (Vasavakul, 2000).

The main aim of nursery education in Vietnam in the 1960s was pre-determined, starting from 1958. The new conception affirmed that the main goal of nursery education was to educate children comprehensively from their early ages in different aspects such as physical, moral, intellectual and esthetics. Nursery education should be an essential foundation for the next education levels (Pham et al., 2006). This educational purpose in the new conception focused on children and was clearer than the old ones before 1954. There were two types of institutions in ECE in Vietnam during this period, namely (1) child care centers (for children from 1 year old up to 3 years 
old), and (2) kindergartens (for children from 3 years old up to 6 years old) (Pham et al., 2006). This period promoted the development of private childcare centers as well as private kindergartens in different agencies and state-owned enterprises.

A management system in this period had established the relationship between the MOE and other departments such as the Ministry of Public Health and the Committee for the Protection of Mother and Children. In 1959, after the inter-sectoral conferences were held to discuss the development of private childcare centers and kindergartens, some administrative committees provided funding and staff to the Women's Union to build schools. While the Women's Union cooperated with the MOE in term of teacher education, the Ministry of Public Health and MOE cooperated in taking good care of children's health. Therefore, the combination of different organizations was diversified, although the connection was not always smooth.

In parallel with the strengthening of organizational structure, the issue of teacher education was considered the main goal in this period. MOET detached some teachers to study early childhood education in the Democratic Republic of Germany from 1956 to 1958 (Pham et al., 2006). They became core experts and contributed their knowledge to set up teacher education in ECE in Vietnam. From 1956 to 1960, MOET opened nine short pre-service courses to train teachers in ECE, and there were 812 teachers who completed these courses (Pham et al., 2006). From 1960 to 1964, MOET set up a dedicated training department which focused on preschool education. In this period, the training department created five courses which were 3-8 months for each. Each course had approximately 100 students, including experienced teachers and students graduated from secondary school. All course attendees were female and came from Kinh group. There were a few indigenous learners. At this time, the number of kindergarten classes expanded both in public and private school, especially in big cities such as Hanoi and Hai Phong.

Although the development of ECE in Vietnam from 1955 to 1965 changed dramatically, there were no policies for supporting teachers and no concrete resolutions to innovate ECE. The outcome of ECE was not good enough, and the movement was toward quantity rather than quality (Pham et al., 2006).

From 1965 to 1975, the war in Vietnam became increasingly fierce and this situation caused large-scale evacuation in northern Vietnam. However, the direness of the war did not demolish the education system which was established in North Vietnam and ECE still had great achievements. On January 19th, 1966, Nursery Education Department (Vụ Mẫu Giáo) in MOET was formed. Since then, nursery education was considered a part of the national educational system in Vietnam (Pham et al., 2006). In 1965, the Ministry united the "Vỡ lòng" with the senior class of the kindergarten level (mẫu giáo lớn) in Vietnam (Vasavakul, 2000). In 1966, three levels of kindergarten classes were set up, namely juniors (mẫu giáo bé), intermediates (mẫu giáo nhỡ), and seniors (mẫu giáo lớn). At that time, children between 3 and 5 years old learned in the first two classes while 6- and 7-year-olds learned in the latter one (Vasavakul, 2000). This model of kindergarten classes was maintained until nowadays in Vietnam. However, the average age of the learners has changed. 3- to 4-year-olds learn in junior classes, 4- to 5-year-olds learn in intermediate classes, and 5- to 6-year-olds learn in senior classes. 
In the wartime, although there was a lack of facilities, child care centers and kindergartens upheld and developed. Since 1966, ECE tasks were implemented concretely than before. Regarding teacher education, the number of early childhood teacher training schools was increasing and in the school year 1971-1972, there were 21 schools. This achievement met the need for human resources in ECE. In an ECE meeting held in Lo Xa from October 15th, 1966 to November 3rd, 1966, the primary tasks of nursery education identified include (1) taking care of children's health in order to ensure that children will develop their physical health, and ensuring children comply with hygiene regulations so that their bodies are strong enough to resist illness; (2) cultivating children's virtue; (3) supporting children to develop their attention, observation, curiosity, language and their interest in natural and social phenomena as well as basic science, in addition to helping children to understand and do things in accordance with their ages; (4) fostering children's sense of esthetics; and (5) preparing for children go to primary schools (Pham et al., 2006, p. 128).

In the wartime, socioeconomic status was unstable in North Vietnam, but ECE had certain achievements such as setting up ECE curriculum, teacher training schools and ECE was considered an important part of education system in Vietnam. Although ECE in North Vietnam achieved some expected results, limitations still existed in this period. First, the ECE was only set up successfully in some provinces because of economic barriers and the influence of the war. Second, the number of teachers fluctuated as many teachers left their job because of the low salary and unclear working contract. Also, the teachers' qualifications were not good enough, and in some places, teachers did not have any in-service education or any training before being a teacher. The quality of kindergarten education in North Vietnam before 1975 was not equitable across geographical areas. In many classes, children were placed in classrooms without a teachers' instruction (Pham et al., 2006).

\section{ECE in Southern Vietnam}

It is difficult to find any documents about early childhood education in Southern Vietnam because of the war. The few documents that survived after 1975 showed that ECE stakeholders were concerned about the education system in Southern Vietnam before 1975.

After the French Government officially signed a decision to transfer the management of education to the Government of Vietnam headed by Bao Dai in 1945, MOE promulgated the Decree No. 4 dated August 27th, 1949 and Decree No. 9 dated September 5th, 1949 for the new educational program from primary schools to high schools (Tran, 2014a). In order to prepare for children to go to primary school, the Decree No. 4 asserted that kindergarten will be established soon (Tran, 2014a). However, ECE was not considered a part of the education system until 1972.

The Culture and Education Policy in 1972 stated that education for children ages three to five was referred as preschool education (Giáo dục Tiền học đường), and the primary task of this educational phase was to support children before they enter elementary schools (Việt Nam Cộng Hòa (Republic of Vietnam), 1972). This policy showed clearly the purpose, schemes, and pedagogies for ECE. It affirmed that "Giáo dục Tiền học đường" (preschool education) supported children in improving their health, their sense 
of safety and confidence as well as shaping their lifestyle, their habits and their emotion. It also helps children to develop their ability to converse and adapt to the external world. Preschool education, therefore, assists children to move easily from a family environment to community life. "Schools will give children a chance to express themselves and to play with their peers" (Việt Nam Cộng Hòa (Republic of Vietnam), 1972, pp. 30-31). The objectives of ECE, therefore, were determined and linked to children's needs and their psychophysiology. In addition, "Ấu trĩ viên” (kindergartens) should be set up in villages and hamlet, and semi-boarding kindergartens should be opened in order to support many families. Although it was not necessary to build a big school, it required a suitable garden in each kindergarten. The culture and education policy did not only define the goals of ECE, but it also addressed the pedagogy at this level. For example, it asserted that "art is very helpful in educating children" (Việt Nam Cộng Hòa (Republic of Vietnam), 1972, p. 31).

Although there are limited documents referring to ECE in Southern Vietnam, the Culture and Education Policy 1972 showed clear evidence for the development of ECE in Southern Vietnam after 1945. It indicates that since 1970 the educational models in this region were not influenced by French education, which focused on training few elites in society and was theoretical bias, and the education in Southern Vietnam was affected by American education, which focused on serving majority (Tran, 2014b).

Despite the differences in political and cultural contexts, in both North and Southern Vietnam, ECE had been formed. Although in fact, the implementation was difficult, the achievements reaped in both South and North Vietnam indicated progress in social awareness for the need of ECE. These achievements were an important ground for establishing the foundation for ECE in Vietnam after 1975.

\section{Early childhood education in Vietnam from 1975 to 1986}

After the reunification of Vietnam in 1975, although Vietnam faced many difficulties, they underlined the growth of kindergarten education as preparing children for the first grade through a teacher-centered method of teaching (Vasavakul, 2000). Hence, ECE was no longer seen as out-of-home socialization but rather as part of lifelong learning (Dang \& Boyd, 2014). It took 2 years after the reunification of Vietnam in 1975 to develop ECE in southern Vietnam (Pham et al., 2006; Vasavakul, 2000). In this period, the Committee for Protection of Mother and Children, directly under the Vietnam Women's Union, called for Southern cities and provinces to build more kindergartens and to organize the construction of vocational schools that trained kindergarten teachers. By the end of 1977, the state management of ECE in the Southern provinces was set up completely and integrated with the Northern provinces. In the first 2 years after the liberation, the kindergarten program still followed the content written since the 1960s. However, after the Decision No. 102/QD of January 31 1978, the improved kindergarten program was promulgated and applied throughout the country (Pham et al., 2006).

From 1975 to 1986, the educational system for children under 6 years old in Vietnam was made up of two main components:

(1) Creche education for infants from 2 months to 3 years of age. In charge of this is an organization directly responsible to the Council of Ministers. 
(2) General education, which covers kindergarten (preschool) education for children from 3 to 5 years old, basic general education, secondary general education, complementary education of adults, and the training of nursery and general education school teachers. In charge of this is the Ministry of Education (Vietnam Courier, 1982, p. 11)

Creche education looked after infants from 2 to 36 months old and trained nurses, the main human resources for infant education, using scientific methods to raise these small children. In rural areas, creches began in thatched huts or private homes, and by the end of 1980, the number of infants reached through creches were 45,939 throughout the country. The crèche system benefited women so that they could take part in social activities as equals to men (Vietnam Courier, 1982). Although nursery education/creche education - Nhà trẻ (for children under 3 years old) and kindergarten educationMẫu giáo (for children from 3 to 6 years old) were parts and parcel of the educational system in Vietnam, the administration for the former belonged to a separate Governmental agency, called the Committee for Protection of Mother and Children, and the latter belonged to the MOE until 1987 (Pham et al., 2006). Children from 3 to 6 years old learned in kindergarten which was considered as a basic unit of national education. At that time, preschools were directly run by agricultural cooperatives, factories, or State farms (Vietnam Courier, 1982). A kindergarten school had four main tasks, including (1) developing children's health; (2) training children morally and helping them form good habits; (3) helping children acquire greater intelligence and mental capability; and (4) providing the children with a number of practical skills and elementary working habits (Vietnam Courier, 1982).

Resolution number 14/NQ-TW was approved in January 1979 to reform education. It emphasized that the education of children from birth to age six has been extremely important to shape citizens for the new socialist system. The main target for ECE was "developing the quality of raising children, helping them develop physically, emotionally, and intellectually, and making children ready for their further studying" (Pham et al., 2006, p. 169). In order to better set up a curriculum for kindergarten education, a Committee for Research on the Reform of Kindergarten Education was established in February 1978 by MOE. This committee focused on studying child psychology, teaching pedagogies, and appropriate programs for preschool-age children (Pham et al., 2006).

Decree number 17/HDBT, signed 30 January 1984, was a secure law corridor for the Government at various levels to follow. It affirmed that "kindergartens are basic units of the national educational system of the Socialist Republic of Vietnam" (Pham et al., 2006). Based on this legal procedure, kindergartens were promoted in different places in Vietnam. Since 1975, kindergartens followed the general school calendar, beginning in September and ending in May (Vasavakul, 2000) and teachers were required to have a certificate of teaching for kindergarten (Vasavakul, 2000; Vietnam Courier, 1982). In general, the development of the number of kindergartens between 1975 and 1986 raised the following issues: (1) kindergartens developed faster and more solidly than in the past decade in the whole country; (2) kindergartens distributed in areas including difficult areas such as mountainous areas or highland areas, and new economic zones; (3) kindergarten attracted children who had different background such as children had 
working-class parents and children came from different Indigenous groups; (4) kindergartens separated with "Vỡ lòng" (Beginner class); and (5) semi-boarding schools, which provided day-long services and lunch, tended to be a trend (Pham et al., 2006). The costs of the semi-boarding school were covered by cooperatives with parents (Vietnam Courier, 1982).

The great achievements in Vietnam ECE in the time of war (1945-1975), and the first decade after the reunification was set up successfully and upheld schools for children under 6 years old. However, this difficult time prevented early childhood Vietnamese educators from approaching different theories in the field of child development. Educators in Vietnam only received knowledge from socialist countries such as East Germany and the Soviet Socialist Republics. Also, the thousand years of Confucian ideology, which uphold the role of teacher and teacher-centered approach, affected Vietnamese policymakers and educators in established ECE at the beginning. This meant that before 1986, the ECE in Vietnam did not focus on children-centered approaches and required teachers to follow one model of instruction. Although from 1986 to 1998, the curriculum in ECE was modified and added more requirements for teaching and learning, its characteristics were similar to the curriculum that was set up before 1986. Thus, before 1988, the Program of Care and Education of Preschool Children was the normative program that was confirmed by every preschool (Phan, 2012). In order to distinguish different curricula that were applied in different time periods in Vietnam, in this article, I will add the year when the program was promulgated. The Program of Care and Education of Preschool Children that used before 1998 will be called The before 1998 Program or B1998P. This B1998P was based on the traditional Vietnamese perspective in education that was linked to Confucian ideology and under the influence of Soviet pedagogy. Consequently, it was a conventional top-down and unitary approach to curriculum with a teacher-centered teaching strategy. These features made a rigid discipline and authoritarian atmosphere in preschool in Vietnam before 1998 (Phan, 2012). In addition, these two main features of ECE in the B1998P in Vietnam were affected by the academic emphasis that focused on children's cognitive rather than other domains.

First, the top-down and unitary approach concretized in setting up all learning activities and inflexible didactics that were applied to every preschool class across the country. The B1998P was similar to a school curriculum and prevented teachers from creating different learning activities for children in the class (Phan, 2012; MOET, 2002). According to Phan (2012), the main reason for this phenomenon was the influence of Soviet ECE on Vietnam ECE. As described in the history of ECE in Vietnam, hundreds of Vietnamese educators studied in the Soviet Union, and then they applied the Russian ECE curriculum and teacher training syllabus which was "formal, broad, theoretical knowledge-focused, and ideology rode" (Phan, 2012, p. 94) for ECE in Vietnam. The B1998P focused on learning areas such as maths and arts, and each area was scheduled into lessons while other child-initiated activities and playing were omitted. The B1998P put cognitive aspects before children's self-confidence, independence, and social skills. In addition, this B1998P did not aim to develop children's thinking skills, critical mind, and creativity as a priority. It attached an exaggerated importance to memorizing knowledge and regular drilling skills (Phan, 2012; MOET, 2002). 
Second, the shortcomings of the top-down approach and curriculum worked very well with Confucian ideology, leading to teacher-centricity as another characteristic for ECE in Vietnam before 1998. Preschool teachers instructed by explaining and showing an example, and then children executed teacher's commands. Children's work and answers were expected to be the same as the adult's view (Phan, 2012). The top-down approach in the curriculum discussed above was the first reason for this negative phenomenon. Another underlying reason for this was Confucian traditions that influenced on the treatment of children in a preschool setting. Adult-centeredness is the main feature in Confucian traditions, and as a result, children have to respect and follow adult (McLeod \& Nguyen, 2001; Phan, 2012). This belief explains teachers' central role in the classrooms and is the reason why the teaching style in the B1998P was a one-way process. Children were passive, and teachers had a responsibility to give all the necessary knowledge to the learners. Although there are many shortcomings in the implementation of preschool education in the period before 1986, it cannot be denied that this period marked an important turning point for the formation of ECE in Vietnam.

\section{Early childhood education in Vietnam since 1986}

Since 1986, preschool education in Vietnam has changed dramatically. Thanks to changing perspectives about ECE, the policies of supporting preschool education has been gradually formed and perfected to meet the change in society. The point of view of education, as well as the purpose of preschool education, has been clearly defined after two main times of innovations in 1998 and 2006-2009. In particular, Indigenous education has been investigated, and there are positive changes to narrow the educational gap between cities and remote mountainous areas.

Although the Vietnamese Government tried their best to reconstruct the country, the consequences of the war lead to an economic embargo, and it was not easy to overcome obstacles and difficulties. Therefore, at the Sixth Communist Party Congress in 1986, the Government endorsed the new policy of socialist reform, called "Đổi mới” and Vietnam then moved into a new era of market-oriented socialism. As a result, this innovation caused changes in education, including ECE. The number of children attending kindergarten decreased significantly from 1987 to 1991 because, after 1986, parents had to pay for kindergarten education (Vasavakul, 2000) and they often could not afford to pay because of losing jobs (Pham et al., 2006). In order to encourage parents to send their children to kindergartens, national ECE policies in Vietnam were lodged within two related frameworks. The first was within national education policy, and the second, children's rights. Article 35 of the 1992 Constitution of the Socialist Republic of Vietnam stipulates "Education is the priority in the national policy" (Vietnam National Assembly, 1992, p. 7). Also, Vietnam ratified the UN Convention on the Rights of the Child shortly after it was passed by the UN General Assembly in 1990. Both national plans, therefore, related to these frameworks that were developed by the state's legal commitments, including ECE (Feny de Los y de Los Angeles-Bantista, 2004, p. 75).

In 1987, as mentioned above, the administration of Creches education and Kindergarten in Vietnam were merged. The Central Commission for the Protection of Mothers and Children was replaced by MOE, creating the Department of Preschool Education that looked after children from infants to 6-year-olds. On March 9, 1989, Council of 
Minister approved the Decision No. 23/HDBT that focused on some urgent matters in the field of education and training. This document affirmed that it is necessary to use different approaches appropriate with socioeconomic conditions in each region to develop ECE (Hội đồng Bộ trưởng- Cộng Hòa xã hội chủ nghĩa Việt Nam, 1989). In 1990, the MOE and the Ministry of Higher Education and Secondary Specialized Education, previously two separate entities, were merged to form the Ministry of Education and Training (MOET) (Vasavakul, 2000), and then the Early Childhood Care and Education (ECCE) Department that merged kindergarten and creche/nursery established in 1991 (Boyd \& Dang, 2017). After that merge, the Child Protection and Education Department under the instruction of the MOE set up the project "Development of Preschool Education" in the educational development target 1987-1990. On 3/2/1990 the Minister issued the Decision No. 55/QD "Setting up the curriculum for early childhood education." The project "promotes the socialization of preschool education; develops diversified forms of preschools by setting up public and private schools; and propagandizes the knowledge of raising children for parents" (Pham et al., 2006, p. 254). Then, the MOET issued two main Decisions that regulated how to open a private preschool. The first Decision, 1295/QD, signed in September 19th, 1990, promulgated the regulation on opening family childcare, family kindergarten class, private nursery school, and private kindergarten school. The second Decision, 1447/GDT, promulgated regulations on private preschool on June 6th, 1994 (Pham et al., 2006). Although the socialization in preschool education was mentioned in Vietnam many years before the 1990s, it was the first time when the development of private preschool had been recognized by national law. After that, Government Decree No. 90-CP, dated November 24, 1993, which stipulated the national education framework and the system of diplomas and certificates of education and training in the Socialist Republic of Vietnam, asserted ECCE was one of fine-part national education framework (Vietnamese Government, 1993). Consequently, since 1993, public awareness about the role of ECCE has been raised (Wendy \& Dang, 2017).

The first education law in Vietnam was signed in 1998. Although ECE was considered as one part of the national educational framework, it was not compulsory nor a prerequisite for entry into primary school. The Government tried to create demand among parents and promotes children's participation in ECE through parent education programs and the use of various media for raising awareness (Feny de Los y de Los AngelesBantista, 2004). The 1998 Education Law defined clearly the learners' age and how to support them in the preschool as described below:

- ECE covers "infants from the age of 3 months to 6 years" (Article 18).

- ECE aims "the objectives of ECE are to help children develop physically, emotionally, intellectually and esthetically, in order to shape the initial elements of personality as well as to prepare children for the first grade" (Article 19).

- "The content of ECE must be suited to the psycho-physiological development of children, balanced between nurturing, caring and educating, with a view to helping children develop a harmonious, healthy, and active body; know how to respect, love and regard grandparents, parents, teachers, and elderly persons; form attachments to brothers, sisters, and friends; be frank, forthright, natural, esthetically sensitive and intellectually inquisitive" (Article 20). 
- "The main method in ECE is to help children develop comprehensively through organizing play activities while giving special attention to providing models, collective instruction, and encouragement" (Article 20).

- Three types of institutions implement ECE in Vietnam: (1) nurseries (child care for infants from the age of 3 months up to 3 years); (2) kindergartens (childcare for infants from the age of 3 years up to 6 years), and (3) preschools (incorporating the functions of both the nursery and the kindergarten, childcare for infants from the age of 3 months up to the age of 6 years) (Article 21) (Vietnam National Assembly, 1998).

After the 1998 education law was approved, more attention was paid to the development of preschool education. Since 2000, MOET called for changes in education in order to meet the requirements for modernization and globalization in Vietnam. National policymakers were fully aware of the positive results that early childhood education supplied for Indigenous children, vulnerable children and those who lived in poverty (The United Nations Educational Scientific and Cultural Organization (UNESCO), 2006). There was evidence in Vietnam to show the benefits that children received when learning at least one year in preschool. Their literacy and numeracy improved better than those who did not experience in preschool and went directly to the primary school (UNESCO, 2006). Consequently' in 2002, the Government has identified the six main areas as priorities:

(1) to develop policies and regulations to manage various forms of ECCE service delivery by semi-state and non-state sectors; (2) to develop mechanisms for financing targeted ECCE programs in poor and remote areas; (3) to allocate resources for infrastructure within the annual Government budget; (4) to address working conditions, employment status and professional development of teachers; (5) to strengthen the capacity of the local officials responsible for the management and supervision of ECCE programs; and (6) to improve coordination among the various sectors involved in ECCE from the central to the local levels that work directly with communities and ECCE service providers (UNESCO, 2006, p. 76).

In November 2002, Prime Minister signed the Decision 161/2002/QD-TTg, which was issued to increase investment in preschool education to 2010. The aims of this Decision were to (1) promote the socialization of education; (2) to expand the system of creches/ nurseries and kindergartens in different residential areas and giving priority to socioeconomically disadvantaged and geographically isolated areas; and (3) to create better conditions for children to develop emotionally, cognitively, socially and physically (Prime Ministries, 2002). It was the second time ECE was promoted by the government and socialization of education was put forward as a great idea to develop diversified early childhood education services. There were four mains school models that are mentioned in the decision, namely public preschools, semi-public preschools, private preschools run by social communities or economic organization (mầm non dân lập) and private preschools run by individual or group of people (mầm non tư thục). Public preschools were built mainly in communes with extremely difficult socioeconomic conditions such as in mountainous and border areas. This Decision was a law to encourage ECE in miserable areas and caused positive effects to narrow the gap between disadvantaged families and affluent families. 
In 2005, the Education Law 1998 in Vietnam was revised, and the section about the preschool curriculum was added into this new document. It stated that "the ECE curriculum (1) represents the ECEC objective, which details the requirements for raising, caring and educating children of each age; (2) prescribes the organization of learning activities that aimed at creating conditions for children to develop physically, emotionally, intellectually and esthetically; (3) gives some guidance on how to evaluate the development of children in preschool age." The Minister of Education and Training (MOET) issues a preschool education program based on the evaluation by the National Council for Evaluation of Preschool Education Programs (Article 24, Vietnam National Assembly, 2005). Three types of institutions have implemented ECE in Vietnam since 1998, and they are under the supervision of the MOET (Hamano, 2010). The socialization of education, which was mentioned in the Decision 161/2002/QD-TTg, was also clearly set out in the education law of 2005. It stated in Article 12:

Developing education and building a learning society are the responsibilities of the State and the whole population. The state shall play the dominant role in developing the mission of education; carry out the diversification of schooling types and modes of education; encourage, promote and facilitate organizations and individuals to take part in the development of the mission of education. It is the responsibility of all organizations, families, and citizens to take care of education, to cooperate with schools in realizing the goals of education, and to build a sound and safe educational environment (Vietnam National Assembly, 2005).

According to Hamano (2010), the diversified forms of socialization of education were: (1) diversification of funding for education, (2) diversification of the preschool forms (the privatization of education), and (3) promotion of educational activity projects by non-Governmental actors such as enterprises, and community organizations. Consequently, early childhood education in Vietnam has been expanded in two main forms (1) state-run (public) preschool and (2) non-state (nonpublic) preschool (Boyd \& Dang, 2017). The diversified forms in ECE satisfy the parents' needs and appropriate with the economic status in Vietnam.

Awareness of the need for early childhood education in the community has been improving, and it has required Vietnamese Government to supplement more important policies in order to support ECE. In 2009, Education Law 2005 was mandated and preprimary education for 5-year-old children has become universalized. This change, as well as other positive innovations that mentioned above, have assisted ECE in Vietnam and it made significant progress in the first decade in the twenty-first century. As a direct result of state policies, during the period between 2001 and 2010, the enrollment rates in ECE increased significantly. The rate of 5-year-old children enrolled in kindergarten increased from 72 to 98 percent [Ministry of Education and Training Vietnam (MOET), 2015] and the preschool enrollment rates across 6-week-old children to 5-year-old children increased from 32 to 42 percent (MOET, 2015).

\section{Curriculum and pedagogy reform in ECE in Vietnam}

As discussed above, there were enormous changes in Vietnamese history since 1945 and ECE was established and developed under the concrete guidance of Vietnamese Government. It takes time for educators and learners in Vietnam to change their 
perspectives on education from their traditional view of teachers-centered approach to learner-centered approach because Vietnam is a hybrid nation of three cultural threads-thousands of years of Confucian traditions, five decades of communist ethos, and the recent arrival of Western values (Ashwill \& Thai, 2005). Although the reunification of North and the Southern Vietnam happened in 1975, the economic status in the three following decades was a crisis and required innovation-Doi Moi in 1986. As society morphed from a Government-subsidized economy to a market economy in the last four decades, ideology, as well as public awareness, has been changed. These changes affected the innovations in different fields including education in Vietnam.

Based on some research, several Vietnamese educators confirmed that the socioeconomic transformations have had effects on every aspect of ECE such as financial resources, policy, curriculum and pedagogy (Dinh, 2008; Phan, 2012). It is clear that socioeconomic development since 1986 caused positive effects to enhance public awareness about the importance of ECE. It took around 10 years to stabilize the new society and to overcome the economic recession in Vietnam. After 10 years of this reform, the number of children in preschool increased from 1.7 million learners in 1986 to 2.8 million learners in 1996 (Wendy \& Dang, 2017). After 1986, there were some positive changes in ECE in Vietnam when the improved curriculum was introduced. All of the lessons for each month of a school year were given in detail. The guidelines provided a method for performing each type of school lesson, which was accompanied by detailed suggestions for teachers to prepare their documents before teaching in the class. These guidelines had both advantages and negative effects. They supported teachers to estimate what kind of knowledge should be introduced and what methods could be used in the class. However, the detailed nature of the guidelines led teachers to be dependent on the content of teaching, as well as methods, and they were applied in a mechanical way throughout the country. Also, these guidelines did not offer any specific characteristics nor the practical conditions of each region, each school/class and the different development of each child. Because teachers depended on the schools' general plan and the guidance materials, they were passive, and their creativity was limited. Furthermore, these guidelines were proof for the teacher-centric or direct-instruction approach that was used popularly in Vietnam. It prevented play-based approach, which is considered as core discipline in many education systems in the world (Fleer, 2010), from being used in many Vietnamese schools before 1986. As a result, it was very hard for teachers to design or develop their own program to suit the child's ability, and they simply followed the instruction without considering the diversify from learner's needs. In addition, preschool children acquired knowledge primarily by memorizing or repeating what teachers said. They did not explore and gain new knowledge through experiencing the practice. These shortcomings had been seen in ECE in Vietnam before 1986 and were not overcome until the first Innovation in 1998, which will be discussed further in the next section. Therefore, ECE in Vietnam from 1986 to 1998 still had the characteristics of the B1998P as mentioned above.

There has been two eras of reform in ECE in Vietnam since 1986. First, the education law of 1998 came out into society. This law marked a new step forward from 
the perspective of ECE and affected its curriculum and pedagogy. A new preschool program called the Innovative Program (1998P) was first introduced in 1998 (Phan, 2012). The 1998P was piloted in some kindergartens and then replaced the before 1998 Program throughout the country. The second reform was piloted in 2006 (MOET, 2006) and occurred throughout the country in 2009, namely 2009 Program or 2009P (MOET, 2009). Recently, this 2009P was amended in 2016 (MOET, 2016) and then an updated version (2017P) has been used since February 15th, 2017 (MOET, 2017).

The 1998P proposed some new viewpoints for ECE in Vietnam and asserted that children-centered was a compass and integration was the essence of preschool education. The 1998P appealed to teachers for creating learning activities based on children's interests and characteristics, and giving children a chance to gain new knowledge through firsthand experience and autonomy in learning (Pham et al., 2006; Phan, 2012). The theme-based teaching was used to replace a subject-based curriculum that applied in the B1998P. Some main thematics were introduced with the guidelines, but teachers based their practice in the classroom to implement the theme of teaching. They could choose the number of lessons as well as the content of each lesson that suit with children in their class. Also, teachers were encouraged to apply creatively different strategies in teaching. This 1998P required teachers to design a child-centered environment and set up different open play corners that give children an opportunity to work individually or in small groups. However, the essence of integration was not defined clearly in the 1998P, leading to misunderstandings in practice. Many teachers believed that integration was the combined knowledge from different aspects by adding more information in one lesson. This belief made their lessons to be overloaded and lose focus. In addition, 1998P still introduced learning topics with guidelines about content and implementation, which was an obstacle to applying child-centered teaching (Phan, 2012). Consequently, these shortcomings were considered and solved by the 2009 Program (2009P) that piloted in some preschools from 2006 (MOET, 2006) and then has become the official national curriculum since 2009 (Phan, 2012).

The 2009P improves reforms about child-centered approach and integration that were proposed in 1998P. This 2009P enables teachers and children to have more "autonomy and flexibility in teaching and learning" (Phan, 2012, p. 96). Teachers are allowed to choose the topics as well as the contents of teaching based on children's interests and the actual condition of each religion (MOET, 2009). In addition, the 2009P attaches great importance to individual access to care and education. The program focuses on assessing the progress of the child, thereby facilitating the teacher's adjustment to the educational plan in order to set up activities that are relevant to children's ability.

The 2017P had been changed the expression in some contents such as assessment of children's learning and updated requirements for physical education. However, in general, the perspective in teaching in this program is the same as 2009P. Currently, early childhood education in Vietnam is still gaining interest and support from the Government. The Prime Minister of Viet Nam signed the Decision 1677/DQD-TTg dated December 3rd, 2018 to approve a Project that focuses on the development of 
ECE from 2018 to 2025 (Viet Nam Prime Minister, 2018). This decision emphasizes on child-centered approach and diversify in setting up preschools in order to meet the children's needs. This project also promotes socialization in ECE and invites public-private partnership investment in constructing more schools.

\section{Conclusion}

Through the ups and downs of history, Vietnam has successfully built an ECE system. Over seven decades of development, ECE in Vietnam has made remarkable changes. The change comes not only from the expansion of the number of educational institutions but also from the curriculum and pedagogy that are considered as the most important changes. In general, since the establishment in 1945, ECE in Vietnam has experienced a number of reforms in curricula and changed their views toward pedagogy. The development of Vietnam's early childhood education reflects the ups and downs of the country's historical context and economic conditions. During the war, although the Vietnamese Government tried to develop its early childhood education system to ensure the rights of mothers and children, the shortage of facilities somewhat limited the quality of the ECE in this period. Undergoing two wars, Vietnam's economy was not strong enough to support facilities for preschool education. However, positive changes in educational views and methods were found in the period after 1998. Especially since 2009, the teacher-centered has been replaced by the child-centered approach, making a remarkable movement for ECE in Vietnam. Gradually escaping the influence of teacher-centered pedagogy, Vietnamese ECE is aiming to build a child-centered education, thereby helping learners reach their full potential. However, the question about how ECE in Vietnam meets the demands of practice still exists (MOET, 2015).

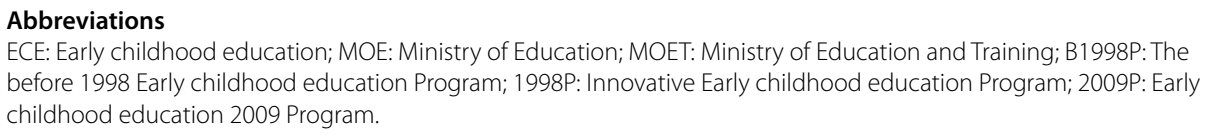

Authors' contributions

As the main author, I wrote my manuscript by myself.

Funding

Not applicable.

Availability of data and material

Not applicable.

\section{Authors' information}

Thao Thi Vu: Ph.D. candidate Murdoch University, Western Australia. Lecturer, Faculty of Early Childhood Education, Hanoi National University of Education, Hanoi, Vietnam.

\section{Competing interests}

None.

\section{Author details}

${ }^{1}$ Murdoch University, Western Australia, Australia. ${ }^{2}$ Faculty of Early Childhood Education, Hanoi National University

of Education, 136 Xuan Thuy, Cau Giay, Hanoi, Vietnam.

Received: 9 April 2019 Accepted: 15 December 2020

Published online: 13 January 2021 
References

Ashwill, M. A., \& Thai, N. D. (2005). Vietnam today: a guide to a nation at a crossroads (1st ed.). Yarmouth, ME: Intercultural Press.

Boyd, W., \& Dang, T. P. (2017). Early childhood education in Vietnam: history and evaluation of its policies. In E. P. J. C. H. Li (Ed.), Early childhood education policies in Asia Pacific: advances in theory and practice (pp. 263-283). Singapore: Springer.

Dang, T. P., \& Boyd, W. A. (2014). Renovating early childhood education pedagogy: A case study in Vietnam. International Journal of Early Years Education, 22(2), 184-196. https://doi.org/10.1080/09669760.2014.909306.

Democratic Republic of Vietnam. (1946). Sắc lênh về đăt những nguyên tắc cơ bản của nền giáo dục mới (The decree sets up the basic principles of the new education). Hanoi, Vietnam Retrieved from https://thuvienphapluat.vn/van-ban/Giaoduc/Sac-lenh-146-dat-nguyen-tac-can-ban-nen-giao-duc-moi/36075/noi-dung.aspx

Dinh, H. T. (2008). Vietnam early childhood education: challenges and development policies to 2015. Paper presented at the Scince of Human Development for Restructuring the "Gap Widening Society", Ochanomizu University, Japan.

Feny de Los y de Los Angeles-Bantista. (2004). Early childhood care and education in South-East Asia, Working for access quality and inclusion in Thailand, the Philippines and Vietnam. Retrieved from http://unesdoc.unesco.org/image s/0013/001378/137867e.pdf

Fleer, M. (2010). Early learning and development: cultural-historical concepts in play. New York, Melbourne: Cambridge University Press.

Hamano, T. (2010). Trends in Early Childhood Education in Vietnam - The "Socialization of Education" and the Management of Disparity. Retrieved from http://www.childresearch.net/projects/ecec/2010_04.html

Hội đồng Bộ trưởng- Cộng Hòa xã hội chủ nghĩa Việt Nam. (1989). Quyết định của Hội đồng Bộ trưởng số 23/HĐBT ngày 9/3/1989 về một số vấn đề cấp bách trong công tác giáo duc và đào tạo. Hanoi, Vietnam Retrieved from https://thuvi enphapluat.vn/van-ban/Giao-duc/Quyet-dinh-23-HDBT-mot-so-van-de-cap-bach-trong-cong-tac-giao-duc-vadao-tao/37725/noi-dung.aspx

McLeod, M. W., \& Nguyen, T. D. (2001). Culture and customs of Vietnam. Westport, CT: Greenwood Press.

Ministry of Education and Training Vietnam. (2002). Guidance for innovating forms of organising activities for 5-6 years old children according to integrated approaches. School year 2002-2003 (Hưởng dẫn đổi mới hinh thức tổ chức hoạt động theo hướng tích hợp cho trẻ mẫu giáo 5-6 tuổi. Năm học 2002-2003). Hanoi: Educational Publishing House

Ministry of Education and Training Vietnam. (2006). Quyết đình Ban hành chương trình thí điểm giáo dục mầm [Decision about promulgation a pilot project that uses new early childhood education curriculum] Hanoi, Vietnam

Ministry of Education and Training Vietnam. (2009). Thông tư của Bộ Giáo duc và Đào tạo số 17/2009 ngày 25 tháng 7 năm 2009: Ban hành chương trình giáo dục mầm non Retrieved from https://luatvietnam.vn/giao-duc/thong-tu-17-2009tt-bgddt-bo-giao-duc-va-dao-tao-44312-d1.html

Ministry of Education and Training Vietnam. (2015). Vietnam National Education for All 2015 review Retrieved from http:// unesdoc.unesco.org/images/0023/002327/232770e.pdf

Ministry of Education and Training Vietnam. (2016). Thông tư sửa đổi, bổ sung một số nội dung của chương trinh giáo dục mầm non ban hành kèm theo thông tư số 17/2009/TT-BGDĐT ngày 25 tháng 7 năm 2009 của Bộ trưởng Bô Giáo duc và Đào tạo [Circular about amending an early childhood education curiculum that issued in circular 17/2009/TT-BGDĐT and signed in 25th July 2009 by Minister of Education and Training] Hanoi Retrieved from https://thuvienphapluat.vn/ van-ban/giao-duc/Thong-tu-28-2016-TT-BGDDT-sua-doi-Chuong-trinh-giao-duc-mam-non-kem-theo-17-2009-TTBGDDT-323937.aspx

Ministry of Education and Training Vietnam. (2017). Thông tư ban hành chương trình Giáo duc mầm non [Circular issued on Early childhood education curriculum]. Retrieved from https://thuvienphapluat.vn/van-ban/giao-duc/Nan-ban-hopnhat-01-VBHN-BGDDT-Thong-tu-Chuong-trinh-giao-duc-mam-non-2017-342703.aspx

Pham, S. T., Le, T. A., Nguyen, T. A., Dinh, T. H., \& Ho, M. T. (2006). 60 năm Giáo dục Mầm non Việt Nam [60 years of Vietnamese Preschool Education]. Hanoi, Vietnam: Nhà xuất bản Giáo duc (Education Publisher).

Phan, H. T. T. (2012). Current curriculum and pedagogy reform in Vietnamese Early Childhood Education: A socio-historic interpretation. In P. W. K. Chan (Ed.), Asia Pacific Education, Diversity, Challenges and Changed. Australia: Monash University Publishing

Prime Ministries, T.T. c. p.-C. H. x. h. C. n. V. N. (2002). Quyết định của Thủ Tưởng chính phủ số 161/2002/Qも-TTG ngày 15 tháng 11 năm 2002 về mồt số chính sách phát triển giáo duc Mầm non [Decision of the Prime Minister No. 161/2002/ QD-TTG of November 15, 2002: a number of policies to develop preschool education]. Hanoi, Vietnam Retrieved from https://thuvienphapluat.vn/van-ban/Giao-duc/Quyet-dinh-161-2002-QD-TTG-chinh-sach-phat-trien-giao-ducmam-non-50228.aspx

The United Nations Educational Scientific and Cultural Organization. (2006). Vietnam Early Childhood Care and Education (ECCE) programmes. Retrieved from http://unesdoc.unesco.org/images/0014/001472/147254e.pdf

Tran, C. V. (2014a). Chương trình giáo duc và sách giáo khoa thời Viêt Nam Công Hòa. Retrieved from https ://sites.google.com/site/namkyluctinhorg/tac-gia-tac-pham/s-t-u-v/tran-van-chanh/chuong-trinh -giao-duc-va-sach-giao-khoa-thoi-viet-nam-cong-hoa

Tran, C. V. (2014b). Giáo dục Miền Nam Việt Nam (1954-1975) trên con đường xây dựng và phát triển (Education in the South ò Vietnam (1954-1975) on the parth of building and development). Tạp chí Nghiên cứu và Phát triển, 7-8(114115). Retrieved from https://boxitvn.blogspot.com.au/2014/12/giao-duc-mien-nam-viet-nam-1954-1975.html

Vasavakul, T. (2000). Managing the young anarchists: kindergartens and national culture in postcolonial Vietnam. In R. W. R. Wollons (Ed.), Kindergartens and cultures: The global diffusion of an idea (pp. 214-250). Connecticut, USA: Yale University Press.

Viêt Nam Công Hòa (Republic of Vietnam). (1972). Cultural and Education Policy. Retrieved from http://www.namkylucti nh.com/a-tailieuvnch/chsachgduc-vankien72.pdf

Viet Nam Prime Minister. (2018). Quyết định 1677/QĐ-TTg phê duyêt Đề án phát triển Giáo duc mầm non giai đoan 2018-2025 [Decision 1677 / QD-TTg Approving the Project on Early Childhood Education Development period 2018-2025]. Hanoi Retrieved from https://thuvienphapluat.vn/van-ban/giao-duc/Quyet-dinh-1677-QD-TTg-2018-De-an-Phattrien-Giao-duc-mam-non-2018-2025-401806.aspx 
Courier, V. (1982). Education in Vietnam. Hanoi: Vietnam Courier.

Vietnam National Assembly. (1992). Hiến Pháp Nước Cộng Hòa Xã hội Chủ nghĩa Việt Nam [The constitution of the Socialist Republic of Vietnam] Hà Nội, Việt Nam Retrieved from http://www.moj.gov.vn/vbpq/lists/vn\%20bn\%20php\%20lut/ view_detail.aspx?itemid $=11243$

Vietnam National Assembly. (1998). Luật Giáo dục [Education Law] Hanoi, Vietnam Retrieved from https://thuvienpha pluat.vn/van-ban/Giao-duc/Luat-giao-duc-1998-11-1998-QH10-44857.aspx

Vietnam National Assembly. (2005). Luật Giáo Dục [Education Law of Vietnam]. Hà Nội, Việt Nam Retrieved from http:// planipolis.iiep.unesco.org/upload/Viet\%20Nam/Viet\%20Nam_Education_Law_2005.pdf

Vietnamese Government. (1993). Nghị định của Chính Phủ số 90-CP ngày 24.11.1993 qui định cơ cấu khung của hệ thống giáo dục quốc dân, hệ thống văn bằng, chứng chỉ về giáo dục và đào tạo của nước Cộng hòa xã hội chủ nghĩa Việt Nam [Government Decree No. 90-CP of November 24, 1993 stipulates for the national education framework and the system of diplomas and certificates of education and training in the Socialist Republic of Vietnam]. Hanoi Retrieved from http://www.moj.gov.vn/vbpq/lists/vn\%20bn\%20php\%20lut/view_detail.aspx?itemid=10645

Wendy, B., \& Dang, P. T. (2017). Early childhood education in Vietnam: history and evaluation of its policies. In Early Childhood Education Policies in Asia Pacific (pp. 263-283). Singapore: Springer

\section{Publisher's Note}

Springer Nature remains neutral with regard to jurisdictional claims in published maps and institutional affiliations.

\section{Submit your manuscript to a SpringerOpen ${ }^{\circ}$ journal and benefit from:}

- Convenient online submission

Rigorous peer review

Open access: articles freely available online

- High visibility within the field

Retaining the copyright to your article

Submit your next manuscript at $\boldsymbol{\Delta}$ springeropen.com 